\title{
FACTORS BEHIND BRAND SWITCHING IN TELECOMMUNICATION INDUSTRY OF PAKISTAN
}

\author{
Sobia Shujaat ${ }^{1}$ \\ Assistant Professor at Bahria University Karachi \\ Dr. Nadeem A. Syed ${ }^{2}$ \\ Associate Professor at SZABIST Karachi \\ Usama Ahmed ${ }^{3}$ \\ Research scholar at the Bahria University Karachi
}

\begin{abstract}
Purpose:- The purpose of this research is to analyze thefactors which encouragebrand switching among customers in telecommunication sector. Due to the low switching cost, the consumers easily shift from one network to another making it essential to study those factors and analyze the consumer switching behavior in telecommunication sector. Hence, this research aims to explore the brand switching behavior of consumer in telecommunication sector.

Methodology:- The data for this research was gathered through use of a structured questionnaire which was duly filled by 500 participants. The participants were students from various universities in Karachi. The Regression analysis, ANOVA and Correlation tests were applied in order to test research hypothesis.

Findings:- The findings reveal that price, brand image, network quality, value added services and promotional activities directly influence consumer switching behavior among youngsters.

Practical implications:- The outcomes of the research can help telecommunication companies in deciding what factors are more important to keep customers loyal and to discourage brand switching.
\end{abstract}

Keywords : value added services, promotional offers, brand image, network quality

Jel Classification: D920, E220, F210

* The material presented by the author does not necessarily portray the viewpoint of the editors and the management of the Institute of Business \& Technology (IBT)

* Sobia Shujaat

* Dr. Nadeem A. Syed

: sobia.shujaat@bimcs.edu.pk

* Usama Ahmed

: nadeem.syed@szabist.edu.pk

C IBTJBS is published by the Institute of Business and Technology (IBT).

Main Ibrahim Hydri Road, Korangi Creek, Karachi-75190, Pakistan. 


\section{INTRODUCTION}

Advancement in communication due to technology has benefited almost all of the industries and resulted in economic growth (Wiehenbrauk, 2010). The telecommunication industry has also gained from it and is one of the fastest growing sector in Pakistan, which contributes around 30\% of the GDP. According to the study shared by Pakistan telecommunication authority, it has been noted that there are around 120.96 milliontelecom users who are availing the services of various mobile networks (Malik et al., 2012).

Brand switching also known as brand jumping refers to the processin which a customer changes from buying one brand of a product to buying another brand(Keller, 2008). In telecommunication sector, the brand switching cost is relatively low, so consumers easily switch to another network, which offers competitive prices and quality. The factor behind consumer brand switching includes negative experience of consumer due to poor product quality or service (Sultana, 2012).

The negative experience gained from product may result in brand switching because the consumer does not prefer to re-buy the product which does not satisfy his need fully.

Moreover, the prices offer by brand and the availability of the brand also result in brand switching. For instance, the consumer prefers to purchase those products, which are available at low prices and high quality (Dodson et al., 1978). However, majority of consumer who are loyal towards their brand do not believe in brand switching. These consumers are committed due to superior quality and services provide by the brand (Colombo and Morrison, 2001).

\subsection{Industry Overview}

Paktel and Insta phone were recognized as the pioneer mobile networks in Pakistan during the year 1990s. Afterwards, with the increase in competition they joined Mobilink thatwas previously owned by Motorolla. Pakistan Telecommunication Authority(PTA) shared that the mobile networking companies are penetrating rapidly in the market;hence there is an increase in the ratio of new customers (Malik et al., 2012). The competition among companies is increasing due to the various packages and offers, which also results in switching cost. The major mobile companies that operate under Pakistan telecommunication industry includeUfone, Warid, Mobilink, Zong, and Telenor.

\subsection{Problem Statement}

In telecommunication sector, the mobile network companies use effective ways to retain their customers, as the customer may shift if not satisfied with their existing network. Hence, the mobile network companies focus towards market research to understand the consumers sated and underlying needs. Therefore to retain consumers, gain consumer loyalty and to reduce the threat of brand switching companies are offering attractive packages. This study is hence important to explore the factors that make the consumer switch towards other cellular network brands.Based on the aim the objectives designed for this research are given below: 
To analyze the factors that prevent form brand switching in the telecommunication sector

To investigate factors that lead consumers towards switching cellular network brand

To recommend strategies through which cellular networking companies can create customer loyalty and can discourage brand switching.

\subsection{Research Hypothesis}

The hypotheses designed for this research are given below:

H1: Price has a significant impact on brand switching in the telecom industry $\mathrm{H} 2$ : Network Quality has a significant impact on brand switching in the telecom industry H3: Brand Image has a significant impact on brand switching in the telecom industry H4: Value Added Services have a significant impact on brand switching in the telecom industry

H5: Sales promotions have a significant impact on brand switching in the telecom industry

\subsection{Research Limitation}

The limitation of research helps in keeping the research focuses towards the topic and specific industry or company. It also helps in limiting the data collection methods and techniques so that study can be completed on given time-frame.The study implies quantitative data. However, this research can also provide qualitativeperspective through approaching managerial views, but because of less time the mixed method was not used.

\section{LITERATURE REVIEW}

The telecommunication sectorcontributesa huge amount inthe national economy. Communication and mobile network is now considered to be the basic need of today's world. Almost $90 \%$ of people are using mobile phones in order to communicate. In cellular networking industry the consumer are of all types from low to middle to high status. Throughunderstanding the market demand and its potential the cellular networkingbrands are gainingadvantagebased on the benefits they are offering.

According to Chaarlas et al. (2012), the ultimate objective of any company is to gain customer satisfaction in order to retain them for long run. Consumer post purchasingbehavior shows that if the product fulfills the consumer need then he will stay loyal will continue buying. However if the product is unable to fulfill his needs, he will be dissatisfied and can switch to other brands by terminating his relationship with existing service provider. In telecommunication industry the switching rates is higherthan in any other industry (Gautam and Chandhok, 2011). This is due to the intense competitionamong cellular networkproviders. The consumerswitch their network service provides due to one of the most importantreason, which is extra benefits and value, added services (Kouser, et al., 2012). 
The brand switching is usually effected by in-store display, availability, quality, reliability, price, promotions, responsiveness, empathy, assurance, tangibility etc(Chaarlas et al.,2012). The service quality provide by cellular companyinfluenceconsumerrepurchasing decision. Kouser et al. (2012) emphasized that quality services spreads positive word of mouth which eventually results in higher market share for cellular companies. In the telecommunication sector the quality of services is identified through innovation, communication and value added services.(Makwana et al., 2014). The markets use various tactics in order to encourage brand switching such as heavy advertising. Prices are also one of the major factors, which convinceconsumers towards switching their cellularnetwork.

The most tricky situationis to identify the challenges that are faced by decision makers to understand theirmarket environment. The primary occurrence of brand switching is due to stochastic reason, utility maximization, and expectationdisconfirmation. The stochastic reason shows that the switchingbehavior of a consumer is not in the control of the service provider. When the consumer moves from one place to another, hechoosethe financial service provider which is near from his area. In this way, the stochastic reason of individual will not change the purchasing probability of previous brand (Lees et al., 2005).

According to Zeithaml (2000) as cited by Lees et al., (2005) reasons for expectationdisconfirmation include brand switching. In this aspect, the consumer evaluates the overall product or service consumptionexperiences. Based on the satisfaction and perceived performance the consumer make further decisions.; for instance if any cellular brand is unable to provide quality services and the consumer might suffer from poor signal, so due to ineffective performance and poor experience the customer might switch towards another network service provider. In telecommunication industry the value added services is most commonly used practice and it is known as non-core services. Previously in cellular networking industry the technology such as mms, SMS, data access was recognized as value-added services but with the passage of time these services become primary services (Lees et al., 2005).

Afzal et al., (2013) shared that in consumer purchasing and repurchasingbehaviorthe brandswitchingbehavior plays a significant role because in daily life the consumerswitch brand more frequently based on the perceivedexperiences. Sathish et al., (2011) explained that price is the most important factor, whichinfluence consumer purchasing decision. The service provider needs to enhanceconsumer brand loyalty through offering fair prices and services. (Sathish et al., 2011).Ashraf et al., (2013) explained the importance of network quality, service quality, coverage and voice claritybeing most important to consumers. However company image is very critical to network provider and is built through proper brand management and the strategies used by companies in order tomaintain the brand position in the market (Baohong et al., 2003). In the telecommunication industry of Pakistan the cellular networking companies are using various sale promotion offers in order to attract customers. Sales promotions includepremiumprizes, coupons, etc. In consumer brand-switching behavior the promotionalcampaignsaids attracting new customers. Those cellular networking 
companies who are using promotional tools more often are able to gain higher market shared and customers (Islam and Rima, 2013).

Kotler (2009) explained that in preventing consumer from brand switching, the company needs to adopt strategies such as competitive pricing and differentiation.

Thecompetitivestrategies used by cellular network brand do influence consumer post purchase behavior and makes them stay with the existing network.

\section{RESEARCH METHODOLOGY}

This studyis descriptive and quantitative in nature and is based on positivism philosophy. Itimplies deductive strategy and the data includes facts, which are shared by research respondents.

Hypotheses were designed and tested further.Primary sources were used in order to gather research data. As the research aims to explore consumer perspective towards brand switching, hence the respondents comprised of five major cellular network brands users in Pakistan.The questionnaire was based on close-ended questions, which were analyzed on a five point likert scale ranging from strongly agree to strongly disagree. The sampling technique chosen for the study was non-probabilistic sampling among which convenience-sampling technique was selected.Hence, based on availability and convenience the research participants were approached.

The sample size comprisedof 500 respondents including both male and female students from three reputable business schools of Karachi. The data collection is limited to consumers that belong from Karachi. Furthermore, the questionnaires were distributed through the help of personal survey and email. social networking sites were also used for data collection. The descriptive analysis was carried out in order to present the views of participants in detailed manner.Moreover, in order to test hypothesis, linear regression analysis and Pearson correlation test was performed. Furthermore, reliability analysis was also performed which aims to study the Cronbach Alpha value.

\section{DATA ANALYSIS AND FINDINGS}

The data in this section is gathered through the help of quantitative method.Furthermore, in order to test research hypothesis regression and correlation test are applied so that dependency among variables can be proved.

\subsection{Reliability Analysis}

From table 1, it is interpreted that the value of Cronbach's Alpha is 0.790 , which is greater than .75 showing the inter item consistency among the constructs in the questionnaire.

\subsection{Multiple Regression Analysis}

The model summary table illustrates linear regression analysis conducted for testing the hypothesis. The dependent variable was brand switching in the telecommunication 
industry and independent variable included prices, netwo rk quality, value added services, brand image and promotional offers. Table 2 reveals the $\mathrm{R}$ square value, which is 0.868 . The value depicts that the relationship among variable is $86.8 \%$, which proves that the model is strong.

The above table reveals the $\mathrm{F}$ distribution value, which is 166.007 , that is greater than 4. This depicts that the hypothesis were all accepted. Furthermore, the sig value is .000 , which is lesser than 0.05 . The significant value proves that price, network quality, value added services, brand image and promotional offers by network provider all play significant role on consumer brand switching behavior.

The coefficient table proves the further validation of research hypothesis through studying $\beta$ value. The above table shows $\beta$ value of 0.751 , which shows positive relationship between price and brand switching. Similarly the value of t is 11.508 which is greater than 1.96 with significant value of 0.000 Therefore, it is proved that the hypothesis is accepted.

$\beta$ value of -0.075 , which shows negative relationship between network quality and brand switching. Similarly the value of $t$ is -57.018 which is lesser than 1.96 with significant value of 0.005 Therefore, it is proved that the hypothesis is accepted.

$\beta$ value of 0.134 , which shows positive relationship between brand image and brand switching. The value of $t$ is 11.419 which is greater than 1.96 with significant value of 0.009 . Hence the hypothesis is accepted.

$B$ value of 0.071 , which shows positive relationship between value addition services and brand switching. The value of $t$ is 45.751 which is greater than 1.96 with significant value of 0.012 . Hence the hypothesis is accepted.

$B$ value of -0.029 , which shows negative relationship between promotional offers and brand switching. The value of $t$ is -23.335 which greater than 1.96 with significant value of 0.023 is. Hence the hypothesis is accepted.

The two-tailed test was conducted which is further interpreted in table 5.

\section{DISCUSSION}

Evaluations of Factors behind brand switching in Telecommunication Industry in Pakistan

\subsection{Price}

According to the study conducted by (Baohong et al., 2003) it is justified that the consumers get dissatisfied when the network brands are charging higher than the services provided by them. The result reveals that such type of actions results in negative reaction of consumer which not only threat company image but it also results in negative word of mouth. Hence, based on above justification it is illustrated that the first hypothesis of research was proven and accepted because in consumer brand switching the prices plays significant role. 


\subsection{Network quality}

Consumers prefer to use those services which are accurate and good value for money. The high network quality provided by companies do influence on consumer toward utilizing the services. Such type of action positively influences consumers and encourage brand switching. However, if the existing brand is able to maintain the service or network quality then consumer does become loyal due to the satisfaction level, even if the prices are high. Literature also justifies that based on network quality and coverage the cellular networking brand is gaining competitive advantage in Pakistan (Ashraf et al., 2013).

\subsection{Brand Image}

It is revealed through literature that positive brand image results in greater brand equity and consumer preference towards a brand due to its market position and due to the higher demand of the brand among their social circle. This is because the company is able to build social image of brand and compete with others. Brandimage also help companies to attract other network users and prevent consumer switching behavior for their current customers (Baohong et al., 2003).

\section{$5.4 \quad$ Value added services}

Value added services include the extra benefits offered by companies that attractscustomertowards their brand. Studies indicate that cellular networking brand of Pakistan are offering value added services such as sports updates, horoscope updates, music updates, news etc which help customers in keeping themselves updated towards their interested area. (Sloot andVerhoef, 2008).Furthermore, based on 3G and 4G technology the cellular networking brand are offering various packages, which includes additional services too.

\subsection{Promotions offers}

Promotional offers include various campaigns and discountoffers provided by brands. In the literature it was studied that cellular networking companies in Pakistan are offering various promotional offers such as "simlagaooffers", "Ramadan packages"etc. These encourages consumer switching to their brands (Islam and Rima, 2013). The findings gathered through the literature also shows that majority of participants are switching their band due to promotional offers and activities adopted by cellularnetworkingbrands in Pakistan.

\section{CONCLUSION}

It is revealed that factors such as price, brand image, service or network quality, value added services and promotional activities plays significant role in influencing consumers brand switching behavior in telecommunication industry. The result of this research proves that with the passage of time and technological advancementnot only society benefits from the services offered but it also profits businesses in expanding. In this way, the first objective, which was related to preventing consumer brand switching behavior proves that the cellular networking companies can upgrade their service level and network quality in order to make their customer loyal. Hence companies can 
maintain long-term relationship with them and prevent their behavior towards switching their brand.

The second objective of this research is investigation of factors that lead consumer towards switching their brand. The outcome of this research proves that factors such as price, quality, brand image, value added services and promotional activities are the factors that trigger that influence consumers' behavior. These factors can prevent or encourage towards brand switching. The analysis shows that if their existing network company is unable to provide high quality network then the consumer might switch towards another brand. The companies are also differentiatingthemselvesthrough utilizing various promotional and value added services.

The research also suggests various strategies that can be utilized by cellular networking brand in order to retain their customers. Furthermore, all the proposed hypotheses were accepted with the sig value of 0.00 , which shows that the price, quality, brand image, value added services and promotionalactivitiessignificantly influence consumer brand switching behavior.

It is revealed that when the consumer is paying money on services/ product then he expects equal or greater value in return and if his current brand is unable to fulfill his expectations than he is more like to switch brand. In this way, those companies not only bear financial loss but it also results in negative word of mouth for their company. It was further emphasized by the respondents that in cellular networking industry the customer loyalty is at low level because of more competitive strategies applied by counter companies in telecommunication industry.

\section{RECOMMENDATIONS}

In order to keep the customer engaged and retain customers, telecommunication companies needs to focus towards their servicequality, price, customer satisfaction, marketing and promotional strategies (Heerde, Gupta and Wittink, 2003). The following strategies can be adopted in order to prevent consumer from brand switching:

The companies should upgrade their network quality and coverage because in cellular networking industry the consumer's core concern is towards the quality. Therefore, in order to value the money spent by customer the companies need to provide quality services. In this way, regardless of high prices the consumer will stay loyal towards the network.

The cellular networking companies can retain their customer through various loyalty programs. These loyalty programs can be in from of membership. Thecellularcompanies can partner with various clubs, resorts, apparels brand and food brands by providing promotional offer such as discount offers.

The most important tool to retain customer and prevent their switching behavior includes the customer relationship management. The companies should manage their relationship with customers by updating them via email or sums, assisting them in the best possible manner and by showing empathy towards them.

The cellular networking companies need to build positive brand image so that it can appeal customers towards remaining loyal with the cellular network provider.

The companies can also assure customers that they will satisfy the need of customers and maintain trustworthy relationship for long-term. This will build positive 
image in customer minds and they will develop feeling that the brand does deliver what it promises.

The cellular networking companies needs to utilize modern communication technology and provide greater value for money to create customer delight and gain long term loyalty.

\section{FUTURE RESEARCH}

More variables can be studied to find out factors that preventconsumer from brand switching. Future research can also focus on gathering managerial perspective by including qualitative research design to present in-depth analysis of consumer brand switching behavior. This will help them design strategies to attract customers.

\section{ACKNOWLEDGEMENT}

First of all with a profound gratitude, we are thankful to Almighty Allah forgiving us success, knowledge and understanding without which we would not been capable of completing this research paper.

We are also profoundly grateful to all our family members whose endurance and understanding have played a significant role in our success by sacrificing the important family time and supporting us all over the research work.

We are finally thankful to the editor, reviewers and IBT specially who provided us with the opportunity to publish our research paper in this esteemed journal.

\section{REFERENCES}

Afzal. S., Chandio, A.K., Shaikh, S., Bhand, M., Ghumro, B.A. and Khuhro, A.K. (2013).

Factors behind Brand Switching in Cellular Networks. International Journal of Asian Social Science, 3(2), 299-307.

Ashraf, R.U., Saeed, R., Arshad, H.M., Zaidi, A.H. and Ahmad, W. (2013).

Determinants of Customer Satisfaction: The Case of Pakistan

Telecommunication Industry. Journal of Basic Applied Science Research, 3(1), 251-258.

Baohong, S., Scott, N. and Kannan, S. (2003). Measuring the Impact of Promotions on Brand Switching When Consuemr are Forward Looking. Journal of Marketing Research, 40(4), 389-405.

Chaarlas, L.J., Rajkumar, R., Kogila,N. and Noorunnisha, A. (2012). Service Related Issue Faced by Clients - The Major Cause Behind Brand Switching in Cellular Phone Service Industry. Arabian Journal of Business and Management Review, 7, 33-46.

Colombo, R.A. and Morrison, D.G. (2001). A Brand Switching Model with Implications for Marketing Strategies. Marketing Science, 8(1), 89-99.

Dodson, J.A., Tybout, A.M. and Sternthal, B. (1978). Impact of Deals and Deal Retraction on Brand Switching. Journal of Marketing Research, XV, 72-81. Gautam, P., and Chandhok, A. (2011). Switching Behaviour of Subscribers in India 
Telecom Sector. International Journal of Research in Finance and Marketing. 1(3), 183-191.

Heerde, H.J., Gupta, S., and Wittink, D.R. (2003). Is 75\% of the Sales Promotion Bump

Due to Brand Switching? No, Only 33\% Is. Journal of Marketing Research, 40(4), 481-491.

Islam, M.B. and Rima, A.R. (2013). Factors Affecting Customer Experience in Telecommunication Service and its Importance on Brand Equity: A Study on Telecommunication Companies in Bangladesh. Journal of Contemporary Research in Business, 5(8), 254-262.

Keller. (2008). Strategic Brand Management, 3rded, Pearson Education India. Kotler, P. (2009). Marketing Management: South Asian Perspective, 13rd ed. Pearson Education India.

Kouser, R., Qureshi, S., Shahzad, F.A. and Hassan.H. (2012). Factors Influencing the Customer Satisfaction and Switching Behavior on Cellular Service of Pakistan. Interdisciplinary Journal of Research in Business, 2(1), 15-25.

Makwana, K., Sharman, N. and Arora, S. (2014).Factors Influencing Consumer Brand Switching Behaviour in Telecommunication Industry: An Empirical Study. Prestige- E Journals of Management and Research, 1(1).

Malik, M.E., Ghafoor, M.M. and Iqbal, H.K. (2012). Impact of Brand Image, Service Qualityand Price on Consumer Satisfaction in Pakistan Telecommunication Sector. International Journal of Business and Social Science, 3(23), 123-129. Sathish, M., Kumar, K.S. and Jeevanantham, K.N. (2011). A Study on Consumer Switching Behavior in Cellular Service Provider: A Study with Reference to Chennai. Far East Journal of Psychological and Business, 2(2), 7181.

Sloot, L.M. and Verhoef, P.C. (2008). The Impact of Brand Delisting on Store Switching and Brand Switching Intentions. Journal of Retailing, 84(3), 281-296. Sultana, A. (2012). The Effect of TV Advertisement on Consumers Brand Switching Behavior, Lambert Academic Publishing.

Wiehenbrauk, D. (2010). Collaborative Promotions: Optimizing Retail Supply Chains with Upstream Information Sharing, Springer Science \& Business Media. 


\section{APPENDIX}

\begin{tabular}{|c|c|}
\hline Cronbach's Alpha & N of Items \\
\hline .790 & 4 \\
\hline
\end{tabular}

Table 1: Reliability Statistics

\begin{tabular}{|l|c|r|r|r|}
\hline & \multicolumn{4}{|c|}{ Model Summary } \\
\hline Model & R & R Square & Adjusted R Square & Std. Error of the Estimate \\
\hline 1 & $.932^{\mathrm{a}}$ & .868 & .861 & .51380 \\
\hline a. Predictors: (Constant), Promotional_Offers, Price, Network_quality, \\
Value_added_Services, Brand_Image
\end{tabular}

Table 2: Multiple Regression

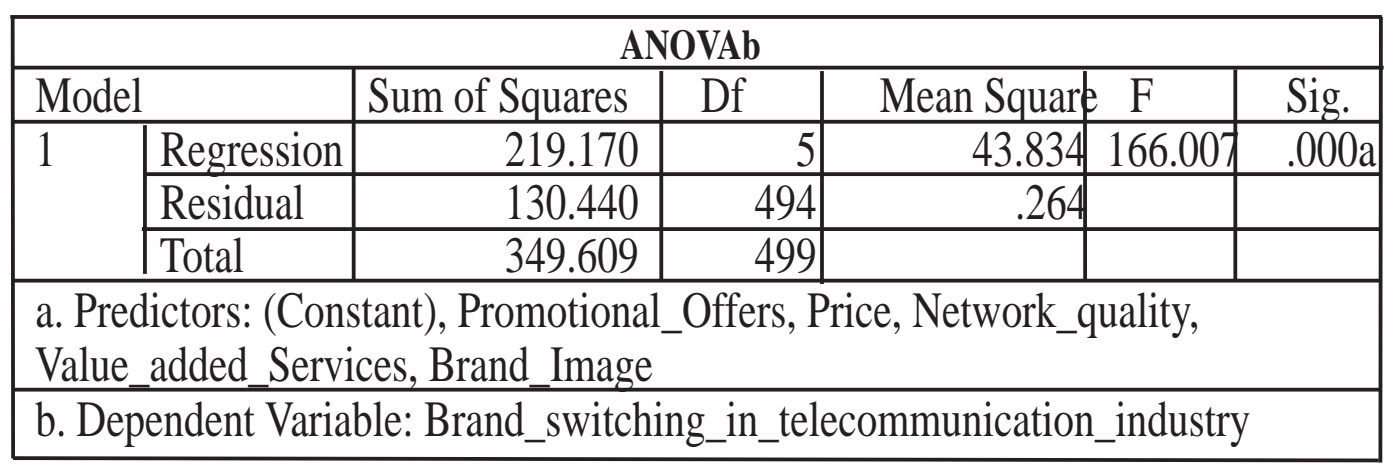

Table 3: ANOVA

\begin{tabular}{|c|c|c|c|c|c|c|}
\hline \multirow{2}{*}{\multicolumn{2}{|c|}{ Model }} & \multirow{2}{*}{\multicolumn{2}{|c|}{ Unstandardized Coefficients }} & & \multicolumn{2}{|c|}{ Coefficientsa } \\
\hline & & & & \multirow{2}{*}{$\begin{array}{c}\begin{array}{c}\text { Standardized } \\
\text { Coefficients }\end{array} \\
\text { Beta }\end{array}$} & \multirow[t]{2}{*}{$\mathrm{T}$} & \multirow[t]{2}{*}{ Sig. } \\
\hline & & & Std. Error & & & \\
\hline \multirow[t]{6}{*}{1} & (Constant) & .891 & .115 & & 7.729 & .000 \\
\hline & \begin{tabular}{|l|} 
Price \\
\end{tabular} & .550 & .048 & .751 & 11.508 & .000 \\
\hline & \begin{tabular}{|l|} 
Network_quality \\
\end{tabular} & -.067 & .066 & -.075 & -57.018 & .005 \\
\hline & Brand Image & .154 & .108 & .134 & 11.419 & .009 \\
\hline & Value_added_Services & .080 & .106 & .071 & 45.751 & .012 \\
\hline & \begin{tabular}{|l|} 
Promotional_Offers \\
\end{tabular} & -.033 & .100 & -.029 & $\mid-23.335$ & .023 \\
\hline
\end{tabular}

Table 4: Coefficient Table 


\begin{tabular}{|c|c|c|c|c|c|}
\hline S.No. & Hypotheses & $\begin{array}{l}\text { Pearson's } \\
\text { Correlation } \\
\text { Value (R) }\end{array}$ & $\begin{array}{l}\text { Relationship } \\
\text { Status }\end{array}$ & $\begin{array}{l}\text { Empirical } \\
\text { Results }\end{array}$ & $\begin{array}{l}\text { Concluded } \\
\text { Interpretation }\end{array}$ \\
\hline H1 & $\begin{array}{l}\text { Price has a significant } \\
\text { impact on brand } \\
\text { switching in the } \\
\text { telecom industry }\end{array}$ & 0.781 & $\begin{array}{l}\text { Strong positive } \\
\text { relationship }\end{array}$ & $\begin{array}{l}0.000< \\
0.050\end{array}$ & $\begin{array}{l}\text { Hypothesis } \\
\text { accepted }\end{array}$ \\
\hline $\mathrm{H} 2$ & $\begin{array}{l}\text { Network Quality has a } \\
\text { significant impact } \\
\text { on brand switching } \\
\text { in the telecom industry }\end{array}$ & -0.721 & $\begin{array}{l}\text { Strong negative } \\
\text { relationship }\end{array}$ & $\begin{array}{l}0.000< \\
0.050\end{array}$ & $\begin{array}{c}\text { Hypothesis } \\
\text { accepted }\end{array}$ \\
\hline $\mathrm{H} 3$ & $\begin{array}{l}\text { Brand Image has a } \\
\text { significant impact on } \\
\text { brand switching in } \\
\text { the telecom industry }\end{array}$ & 0.535 & $\begin{array}{l}\text { Moderate positive } \\
\text { relationship }\end{array}$ & $\begin{array}{l}0.000> \\
0.050\end{array}$ & $\begin{array}{l}\text { Hypothesis } \\
\text { accepted }\end{array}$ \\
\hline $\mathrm{H} 4$ & $\begin{array}{l}\text { Value Added Services } \\
\text { have a significant impact } \\
\text { on brand switching in } \\
\text { the telecom industry }\end{array}$ & 0.541 & $\begin{array}{l}\text { Moderate positive } \\
\text { relationship }\end{array}$ & $\begin{array}{l}0.000< \\
0.050\end{array}$ & $\begin{array}{l}\text { Hypothesis } \\
\text { accepted }\end{array}$ \\
\hline H5 & $\begin{array}{l}\text { Sales promotions have } \\
\text { a significant impact on } \\
\text { brand switching in } \\
\text { the telecom industry }\end{array}$ & -0.508 & $\begin{array}{l}\text { Moderate negative } \\
\text { relationship }\end{array}$ & $\begin{array}{l}0.000< \\
0.050\end{array}$ & $\begin{array}{l}\text { Hypothesis } \\
\text { accepted }\end{array}$ \\
\hline
\end{tabular}

Table 5: Two-Talled Test 